Rafał Bakalarczyk

\title{
Kwestia opiekuńcza w agendzie polityki senioralnej w Polsce
}

\begin{abstract}
Streszczenie
Artykuł poświęcony jest współczesnej agendzie polityki senioralnej w Polsce w kontekście zagadnień związanych z opieką długoterminową i usługami opiekuńczymi wobec osób starszych. W pierwszej części definiowane są zasadnicze pojęcia jak „,agenda”, „polityka senioralna” czy rozumienie „kwestii opiekuńczej”. W następnej części dokonano przeglądu dokumentów różnych podmiotów publicznych w zakresie działań na rzecz osób starszych pod kątem tego, czy i jak obecne są w nich zagadnienia związane z opieką. $\mathrm{Na}$ tej podstawie rekonstruowana jest agenda polityki senioralnej w aspekcie opiekuńczym. Najpierw omawiane są dokumenty i programy rządowe, a następnie działalność innych podmiotów, jak Rzecznik Praw Obywatelskich, Najwyższa Izba Kontroli czy Urząd Ochrony Konkurencji i Konsumenta. Artykuł wieńczą wnioski.
\end{abstract}

Słowa kluczowe: opieka długoterminowa, osoby starsze, niesamodzielność, agenda polityki społecznej, starzejące się społeczeństwo, polityka senioralna, opieka 75+, Rzecznik Praw Obywatelskich, Program ASOS, Program Senior-Wigor

\section{The Long-Term Care Issue in the Agenda of the Policy for Senior Citizens in Poland}

\begin{abstract}
The article is about the contemporary agenda of the policy for senior citizens in Poland, concerning especially the long-term care issue. In the first part, there are key concepts of the article defined, such as "agenda in the public policy", "policy for senior citizens" and long-term care issue". In the second part, there are several policy documents and programmes for the aged examined, which provides the overview of the current elderly and long-term policy and its agenda. The analysis includes the governmental documents and programmes, as well as the activity (concerning long-term care for the elderly) of some other central institutions such as the Ombudsman and Supreme
\end{abstract}


Audit Office and Office of Competition and Consumer Protection. The article ends with the conclusions.

Keywords: long term care, senior citizens, elderly, policy agenda, elderly care

Podwójnemu starzeniu się populacji towarzyszy wzrost potrzeb opiekuńczych. Rośnie liczba różnych wyzwań powiązanych z ich zaspokajaniem. Poniżej próbuję odpowiedzieć na pytanie, czy i w jakim zakresie rodzima polityka senioralna - wyodrębniona w Polsce w pierwszej połowie drugiej dekady XXI wieku - uwzględnia te wyzwania. W tym celu analizuję dotychczasową agendę polityki senioralnej pod kątem obecności w niej problemów i potrzeb związanych z opieką długoterminową, a także próbuję wskazać i przenalizować działania, które instytucje polityki publicznej projektują i wdrażają.

Z uwagi na to, że analiza będzie dotyczyła agendy, wymagać będzie ona już na wstępie przypomnienia znaczenia tego terminu w polityce publicznej i jej badaniach. Następnie zostanie dookreślone rozumienie polityki senioralnej wraz z omówieniem stanu badań tej dziedziny w Polsce, a także krótka charakterystyka problemów, które składają się na kwestię opiekuńczą w Polsce. W kolejnej części dokładniejszemu oglądowi - pod kątem obecności zagadnień opiekuńczych - poddane zostaną wiodące dokumenty polityki publicznej, wyrażające działania ważnych instytucji współkształtujących agendę tej dziedziny polityki publicznej na poziomie centralnym. Artykuł zwieńczą wnioski, ale także rekomendacje dalszych kierunków badań i działań o charakterze publicznym.

\section{Agenda w polityce publicznej}

Termin „agenda” w nauce o polityce publicznej funkcjonuje w dwóch znaczeniach, które za B. Szatur-Jaworską możemy określić jako statyczne i dynamiczne ${ }^{1}$. Temu pierwszemu odpowiada choćby definicja T. Birklanda, zgodnie z którą agenda to „zespół centralnych problemów, które przyciągają uwagę społeczeństwa oraz jego funkcjonariuszy rządowych"2. Z kolei w ujęciu dynamicznym reprezentowanym przez M.E. Krafta i S.R. Furlonga agenda postrzegana jest bardziej jako pewien

1 B. Szatur-Jaworska, Polityka senioralna w Polsce - analiza agendy, „Problemy Polityki Społecznej. Studia i Dyskusje" 2015, nr 30, s. 48.

2 T. Birkland, Agenda Setting in Public Policy, w: Handbook of Public Policy Analysis. Theory, Politics and Methods, red. F. Fischer, G.J. Miller, M.S. Sydney, CRS Press, 2007, s. 63, za: A. Zybała, Polityki 
proces „definiowania problemu publicznego, sposób jego postrzegania, nadawania mu określonego miejsca $\mathrm{w}$ hierarchii ważności wśród innych problemów publicznych”3. W dalszej części będę - podobnie jak B. Szatur Jaworska - analizował agendę polityki senioralnej w jej ujęciu statycznym, bliskim rozumieniu zaproponowanemu przez T.A. Birklanda. Autor ów wprowadza również trzy poziomy rozumianej przez siebie agendy: powszechny, systemowy i instytucjonalny. W artykule będę analizował głównie ten ostatni poziom, czyli agendę instytucjonalną, rozumianą jako „lista ściśle wyselekcjonowanych zagadnień, które stają się przedmiotem namysłu różnych uprawnionych władz"4. Przydatne wydaje się także określenie szczebla podmiotów i działań publicznych, które będą podlegały analizie. Może to być poziom ponadkrajowy, krajowy, regionalny czy lokalny. W niniejszym artykule autor skoncentruje się przede wszystkim na szczeblu krajowym, zaś niższe poziomy, tj. regionalny i lokalny zostaną przywołane pod kątem agendy polityki senioralnej - np. w kontekście wyników jednego z raportów NIK ${ }^{5}$ - co najwyżej na prawach dygresji. Wprawdzie, jeśli chodzi o analizy agendy polityki senioralnej, na polskim gruncie szlak został już przetarty, niniejszy artykuł ma jednak za zadanie wnieść pewne novum względem po wielokroć cytowanych (także w dalszej części pracy) publikacji prof. B. Szatur-Jaworskiej. Po pierwsze, autor chciałby skoncentrować uwagę nie na całokształcie zagadnień wchodzących w skład polityki senioralnej i jej pozycji w szerszej agendzie polityki publicznej, a na wątkach związanych z niesamodzielnością i opieką długoterminową oraz ich usytuowaniu w agendzie (głównie instytucjonalnej) polityki senioralnej na poziomie krajowym. Po drugie, analiza nie będzie kończyła się na 2015 r., ale uwzględni także to, co działo się w agendzie polityki senioralnej po 2015 r. Po trzecie, analizie autor chciałby poddać nie tylko podmioty wykonawcze władzy publicznej, właściwe do spraw polityki senioralnej (tj. przede wszystkim departament polityki senioralnej w Ministerstwie Rodziny, Pracy i Polityki Społecznej), ale także podmioty, których skądinąd bogata działalność na tym polu bywa pomijana. Chodzi o dorobek Rzecznika Praw Obywatelskich, Najwyższej Izby Kontroli czy Urzędu Ochrony Konsumentów i Konkurencji. Działania wspomnianych instytucji, badających wybrane obszary funkcjonowania państwa i życia społecznego i na tej podstawie identyfikujących problemy do rozwiązania, tworzą agendę, mogą się przełożyć na określone działania publiczne, w tym kroki prawne. Wydaje się, że

publiczne. Doświadczenia w tworzeniu i wykonaniu programów publicznych $w$ Polsce $i$ w innych krajach, KSAP, Warszawa 2012.

3 M.E. Kraft, S.R. Furlong, Public Policy, Politics, Analysys, and Alternatives, CQPress, 2017, s. 72-75.

4 B. Szatur-Jaworska..., op.cit.

5 Najwyższa Izba Kontroli, Informacja o wynikach kontroli „Świadczenie pomocy osobom starszym przez gminy i powiaty", Warszawa 2016. 
usytuowanie zagadnień z zakresu opieki nad niesamodzielnymi osobami starszymi w kręgu problemów do rozwiązania, z uwagi na ograniczone możliwości ich eksploracji i wyartykułowania ze strony zorganizowanych i wpływowych grup interesu, szczególnie silnie może zależeć od aktywności publicznych instytucji o charakterze kontrolnym czy rzeczniczym. W jakim stopniu instytucje wykorzystują ów potencjał, zostanie przeanalizowane w dalszej części artykułu. Autor celowo uchyli się od analizy agendy instytucjonalnej wyłącznie przez pryzmat aktów prawnych, uznając, że równie ważne, a nie zawsze uwzględniane $\mathrm{w}$ analizie kształtowania czy zawartości agendy polityki publicznej są podejmowane przez podmioty publiczne działania o charakterze rozpoznawczym i ukierunkowującym przyszłe działania. To tworzenie ram, diagnoz i wytycznych ma znaczenie tym większe, $z$ im bardziej „młodą” dziedziną mamy do czynienia, która dopiero kształtuje swoją pozycję i status w polityce publicznej i jej agendzie. Taka sytuacja występuje zarówno w wypadku szerszej polityki senioralnej, jak i budowania nowoczesnego systemu opieki długoterminowej nad osobami starszymi i niesamodzielnymi.

\section{Polityka senioralna jako jedna z dziedzin polityki publicznej}

Skoro zdefiniowana została agenda w polityce publicznej, warto wskazać, czym jest polityka publiczna określana mianem senioralnej. Samo pojęcie polityki senioralnej jest relatywnie nowe zarówno w naukach o polskiej polityce publicznej, jak i jako dział polityki publicznej realizowanej poprzez praktyczne działanie instytucji publicznych. Sama polityka publiczna jako nauka również jest dyscypliną młodą (formalnie funkcjonuje w systemie nauk od 2011 r.). J. Woźnicki, omawiając specjalności polityki publicznej, nie wspomina o polityce senioralnej jako jednym z jej przykładowych rodzajów. Polityka senioralna ani bliskoznaczny zamiennik tego pojęcia nie pojawiają się też jako specjalizacja polityki publicznej - polityki społecznej6. W ostatnich latach jednak kategoria ta coraz częściej pojawia się w publikacjach (a nieraz bezpośrednio w ich tytułach) badaczy związanych ze społecznymi naukami o starzeniu, także tych, którzy przez minione dekady kładli podwaliny pod gerontologię społeczną, np. u wspomnianej B. Szatur-Jaworskiej, E. Trafiałek ${ }^{7}$ czy J. Perek-

6 J. Woźnicki, Nowa dyscyplina - „nauki o polityce publicznej” usytuowana w dziedzinie nauk społecznych, „Nauka” 2012, nr 1, s. 143.

7 E. Trafiałek, Inowacyjna polityka senioralna, między ageizmem, bezpieczeństwem socjalnym i active ageing, Wydawnictwo Adam Marszałek, Toruń 2016. 
-Białas. ${ }^{8}$ W opracowaniach tych znajdujemy pogląd, że kategoria polityki senioralnej wywodzi się na polskim gruncie z praktycznej działalności państwa, w ramach której została instytucjonalnie wyodrębniona. Świadczą o tym nazwy takich instytucji jak Departament Polityki Senioralnej i działająca przy nim Rada ds. Polityki Senioralnej, przyjęty przez nią dokument o nazwie „Założenia wieloletniej polityki senioralnej na lata 2014-2020"9. W tym ostatnim dokumencie polityka definiowana jest jako „Ogół celowych działań organów administracji publicznej wszystkich szczebli oraz innych organizacji i instytucji, które realizują zadania i inicjatywy kształtujące warunki godnego i zdrowego starzenia się"10 i dalej: „Na potrzeby niniejszego dokumentu polityka senioralna rozumiana jest szeroko jako ogół działań, w okresie całego życia człowieka, prowadzących do zapewnienia warunków wydłużenia aktywności, zarówno zawodowej, jak i społecznej, oraz samodzielnego, zdrowego, bezpiecznego i niezależnego życia osób starszych"11. W samej definicji opieka ani opieka długoterminowa nie pojawiają się expressis verbis. W obydwu zdaniach definiujących rozumienie polityki senioralnej dość silny akcent położony jest na życie w zdrowiu. W drugim $\mathrm{z}$ ujęć mowa jest o życiu nie tylko zdrowym, ale także niezależnym, samodzielnym oraz w warunkach do wydłużenia aktywności zawodowej i społecznej. Wszystkie te sformułowania potraktowane razem mogą wywołać wrażenie, że większy nacisk jest położony na te fazy bądź aspekty starości, w których nie mamy do czynienia z zależnością od długoterminowej opieki na skutek wieku, złego stanu zdrowia czy niesamodzielności. Nieco bardziej z potrzebami niesamodzielnych seniorów może kojarzyć się deklarowany cel zapewnienia godności i bezpieczeństwa osobom starszym, ale czy na pewno za tymi pojęciami kryje się wrażliwość na potrzeby i problemy opiekuńcze - nie jest oczywiste. Weryfikacji słuszności tej obawy może posłużyć analiza treści samego dokumentu - w dalszej części opracowania. Choć sama oficjalna definicja polityki senioralnej nie musi przesądzać o szczegółowej treści realizowanych na odcinku senioralnym działań, próba definicji pochodzącej właśnie z tego dokumentu ma jednak szczególne znaczenie. Stanowi ona wyjściową definicję dla powstających opracowań o charakterze naukowym i eksperckim, jak choćby te przygotowane przez wyżej wymienione badaczki. Ponadto dokument ów stanowi ogólne ramy agendy polityki senioralnej na lata 2014-2020.

8 J. Perek-Białas, Tradycyjne i uzupełniajace podejścia do ewaluacji efektów polityki senioralnej, „Problemy Polityki Społecznej. Studia i Dyskusje" 2016, nr 34(3).

9 Uchwała nr 238 Rady Ministrów z dnia 24 grudnia 2013 r. w sprawie przyjęcia dokumentu Założenia Długofalowej Polityki Senioralnej w Polsce na lata 2014-2020, http://www.monitorpolski.gov.pl/ $\mathrm{mp} / 2014 / 118 / 1$

10 Ibidem, s. 4.

11 Ibidem. 
Na meta poziomie zarysowuje się następujące pytanie - czy kwestia opiekuńcza jest rzeczywiście odrębna względem wyzwań społecznych i aktywizacji zawodowej osób w procesie starzenia się? Czy zawsze mamy do czynienia z osobnymi kategoriami osób starszych, mówiąc o potrzebach opiekuńczych i problemach aktywizacji społecznej, czy też zagadnienia te przecinają się? Sposób organizacji opieki długoterminowej wpływa bowiem na przykład na możliwość podtrzymania aktywności społecznej i zawodowej po stronie opiekunów rodzinnych/nieformalnych, którzy też są statystycznie często osobami w okresie senioralnym lub u progu starości. Ponadto osoba zależna od opieki również nie traci potrzeb związanych z uczestnictwem społecznym czy pewnym poziomem niezależności, adekwatnie do możliwości. W zagranicznych opracowaniach pojawiają się także próby patrzenia na tematykę opieki długoterminowej w kontekście aktywnego starzenia się $e^{12}$. Zagadnienia aktywizacyjne i opiekuńcze wydają się zbiegać także w kontekście problematyki wsparcia środowiskowego czy deinstytucjonalizacji.

W kolejnej kadencji rządu (lata 2015-2019) przygotowany został przy Departamencie Polityki Senioralnej nowy dokument pt. „Polityka społeczna wobec osób starszych do 2030 roku"13 mający stanowić podwaliny pod rządową strategię wobec tej grupy. Kategoria polityki senioralnej nie pojawia się, a w jej miejscu umieszczono pojęcie „polityki społecznej wobec osób starszych”, które to na gruncie nauki nie jest z polityką społeczną tożsame. W dokumencie politykę społeczną wobec osób starszych zdefiniowano jako: „celowe, długofalowe i systemowe oddziaływanie państwa oraz innych podmiotów publicznych i niepublicznych na kształtowanie warunków prawnych, ekonomicznych oraz społecznych w celu tworzenia osobom starszym korzystnej dla nich sytuacji dostosowanej do zmieniających się wraz z wiekiem potrzeb społecznych, ekonomicznych oraz opieki i ochrony zdrowia w każdym okresie życia osoby w starszym wieku"14. W porównaniu z definicją polityki senioralnej zawartą $\mathrm{w}$ uprzednio omawianym dokumencie z 2013 r. nie występuje tu bezpośrednie odwołanie do potrzeby aktywności, niezależności i samodzielności, a jest z kolei mowa także o opiece i zmieniających się potrzebach w każdym okresie życia w starszym wieku. Ta zmiana akcentów w samych definicjach może sugerować pewne przesunięcie punktu ciężkości w kierunku działań wobec osób starszych, o mniejszej sprawności, zagrożonych niesamodzielnością i wymagających intensywnej opieki zdrowotnej i długoterminowej. Do tego rodzaju przypuszczeń może skłaniać także

12 G. Ruppe, Active Ageing and Prevention in the Context of Long-term Care, European Centre of Social Welfare Policy and Research, Policy brief., Wien 2011.

13 Polityka społeczna wobec osób starszych do 2030 roku.

14 B. Szatur-Jaworska, Polska polityka społeczna wobec starzenia się ludności w latach 1971-2013, Dom Wydawniczy Elipsa, Warszawa 2016. 
silne podkreślenie i wyodrębnienie w omawianym dokumencie działań na rzecz osób dotkniętych niesamodzielnością (aczkolwiek, jak pokazały rozważania wyżej, jest kwestią do dyskusji, czy działania wobec niesamodzielnych seniorów powinny być wyodrębnione z innych sfer działania publicznego w związku ze starzeniem się społeczeństwa). Warto też dodać, że choć w definicji tytułowej polityki społecznej nie ma odniesień do aktywności i niezależności, propozycje autorów dokumentu także obejmują działania na rzecz podnoszenia i podtrzymania aktywności osób starszych. Co więcej, tego rodzaju wytyczne znajdujemy nie tylko w pierwszym dziale (obszar działań wobec seniorów ogółem), ale również w drugim (obszar działań wobec osób niesamodzielnych).

Interesujące, że zarówno z obecnie konsultowanego dokumentu, jak i realizowanej dotąd polityki senioralnej w ramach wyznaczonych przez wspomniany dokument „Założenia...” wyłączony jest obszar zabezpieczenia emerytalnego, kształtowany przez innych aktorów polityki publicznej. Jest to ciekawe o tyle, że przez dekady problemy osób starszych w ramach polityki publicznej były analizowane właśnie przez zagadnienia emerytalne. B. Szatur-Jaworska, szukając odpowiedzi na pytanie o genezę wyodrębnionej polityki senioralnej akurat w latach 2012-2013, upatruje wyjaśnienia m.in. w chęci pokazania troski o sprawy senioralne jako swego rodzaju społecznej przeciwwagi dla budzących kontrowersje zmian w systemie emerytalnym (podwyższenie ustawowego wieku emerytalnego, przeniesienie części składki OFE do ZUS) ${ }^{15}$. Jeśli przyjęlibyśmy powyższą argumentację, można by powiedzieć, że pojawienie się polityki senioralnej w agendzie publicznej jest poniekąd wtórne wobec kwestii emerytalnej, bowiem to zmiany w tej ostatniej sferze w istotnym stopniu przyczyniły się do otworzenia pola do rozwoju działań w innych obszarach funkcjonowania osób starszych. Jakie miejsce wśród tych obszarów zajmuje kwestia opiekuńcza? Przyjrzyjmy się temu, jakie problemy na nią się składają i jakie są ich uwarunkowania.

\section{Jakie problemy składają się na kwestię opiekuńczą w Polsce}

Kwestia opiekuńcza ${ }^{16}$ wiąże się z jednej strony z rosnącym udziałem osób wymagających długotrwałej opieki i wsparcia w codziennym funkcjonowaniu, zwłaszcza

15 Ibidem.

16 Kwestię opiekuńczą traktuję jako zbiór powiązanych ze sobą problemów systemowych odnoszących się do zapotrzebowania na opiekę. Pojęcie „kwestii społecznej” być może jest mniej popularne na gruncie nauk o polityce publicznej, ale ma długą tradycję na gruncie nauk o polityce społecznej, por. np. J. Danecki, 
wskutek starzenia się populacji, z drugiej zaś z trudnościami zaspokojenia ich potrzeb $\mathrm{w}$ ramach istniejącego układu instytucji, z rodziną włącznie. Pierwsze zjawisko nie wymaga dokładniejszego wyjaśnienia, rośnie bowiem w populacji odsetek najstarszych mieszkańców, a to właśnie w podeszłym wieku ryzyko niesamodzielności jest największe. Towarzyszy temu także spadek udziału osób w wieku produkcyjnym, co zwiększa poziom obciążenia demograficznego. Ów spadek jest potęgowany kierunkiem ruchów ludności, który w polskich realiach cechuje znaczna skala migracji wśród ludności w wieku produkcyjnym. Ogranicza się w związku z tym możliwość bezpośredniego zaangażowania w opiekę. Ponadto niewielka liczba osób młodszych w relacji do najstarszych prowadzi do trudności uzyskania wpływów sektora publicznego, pochodzących z podatków i składek, z których finansowane mogłyby być wspólnotowe sposoby zaspokajania potrzeb osób niesamodzielnych w starszym wieku i ich bliskich. Na ogólne uwarunkowania wyzwania opiekuńczego, które obserwowane są także w innych krajach rozwiniętych ${ }^{17}$, nakładają się konkretne problemy związane $\mathrm{z}$ nierozwinięciem, niedostosowaniem i nieprawidłowościami systemu opieki długoterminowej w Polsce. Całościową jego diagnozę wraz z zarysem kierunków naprawy przygotowano w ramach publikacji Opieka długoterminowa ${ }^{18}$ pod kierunkiem senatora M. Augustyna. Pracująca pod jego przewodnictwem grupa robocza była w parlamencie VI i VII kadencji ważnym ośrodkiem kształtowania agendy opieki długoterminowej, chociaż jej prace nie doprowadziły do przyjęcia długo przygotowywanych rozwiązań (pod nazwą Ustawy o pomocy osobom niesamodzielnym). Od czasu wspomnianej publikacji powstały też w innych ośrodkach powiązanych z organami polityki publicznej (MRPiPS, NIK, RPO, UOKIK) kolejne dokumenty omawiające problematykę senioralną całościowo, jak i w poszczególnych segmentach systemu opiekuńczego. Dokumenty składają się na analizowaną w artykule agendę i zostaną dokładniej wymienione jeszcze w dalszej części.

Wśród problemów zidentyfikowanych w przywołanym raporcie pod kierunkiem M. Augustyna można wskazać m.in. niedofinansowanie, duże rozproszenie instytucji i aktów prawnych, słabo rozwinięty rynek usług opiekuńczych oraz niewielki udział trzeciego sektora przy jednoznacznie istniejącej szarej strefie opieki ${ }^{19}$. Inne raporty, przygotowane przez poszczególne instytucje publiczne pokazują, że nie tylko w układzie

Kwestie społeczne - istota, źródła, zarys diagnozy, w: A. Rajkiewicz, J. Supińska, M. Księżopolski, Polityka społeczna. Materiały do studiowania, Wydawnictwo „Śląsk” Katowice 1998; J. Hrynkiewicz, Kwestia spoteczna w pracach Ludwika Krzywickiego, Wydawnictwa Uniwersytetu Warszawskiego, Warszawa 2010.

17 Por. np. C. Ranci, E. Pavolini, Institutional Change in Long-term Care: Actors, Mechanisms and Impacts, w: Reforms in Long-term Care Policies in Europe Investigating Institutional Change and Social Impacts, red. C. Ranci, E. Pavolini, Springer, New York 2013.

18 Opieka długoterminowa w Polsce. Opis. Diagnoza, rekomendacje, red. M. Augustyn, Warszawa 2009.

19 Ibidem. 
między instytucjami dochodzi do negatywnych zjawisk, ale także w poszczególnych instytucjach występują liczne nieprawidłowości, łącznie z łamaniem praw człowieka (por. podrozdział poświęcony aktywności UOKiK i RPO).

Na kwestię opiekuńczą składają się nie tylko problemy samych osób wymagających opieki, ale także ich opiekunów, w tym formalnych czy też rodzinnych. Polski model opieki cechuje szczególnie znaczny udział tego sektora. O jego wielkości świadczy nie tyle odsetek osób zaangażowanych w opiekę, ile udział osób deklarujących świadczenie opieki w sposób intensywny, w znacznym wymiarze czasowym ${ }^{20}$. Problemem zarówno o charakterze indywidualnym, jak i systemowym jest niemożność kontynuowania lub podejmowania pracy zawodowej z powodu niesamodzielności osób bliskich i decyzji o sprawowaniu wobec nich długoterminowej opieki. Problem godzenia pracy z opieką, podnoszony coraz częściej w opracowaniach międzynarodowych, budzi zainteresowanie także rodzimych badaczy, o czym świadczą artykuły Ł. Jurka, P. Łuczaka ${ }^{21}$, J. Stypińskiej i J. Perek-Białas ${ }^{22}$ czy A. Furmańskiej-Marusz$\mathrm{czak}^{23}$. Z kolei trudna sytuacja prawno-socjalna opiekunów utrzymujących się ze świadczeń opiekuńczych (w polskim systemie prawnym przyznawanych za cenę całkowitej rezygnacji z pracy) doczekała się badań na tle porównawczym ze strony N. Dzioby-Marskiej ${ }^{24} \mathrm{i}$ w artykułach R. Bakalarczyka, który dynamikę zmian prawnych próbował analizować z odwołaniem do presji ze strony ruchów społecznych (głównie samych osób dotkniętych problemem) oraz aktorów instytucjonalnych (Rzecznik Praw Obywatelskich i przede wszystkim Trybunał Konstytucyjny ${ }^{25}$. Z analiz tych wynika, że wobec istniejącego systemu wsparcia opiekunów można sformułować wiele zastrzeżeń, odnośnie zarówno do wysokości świadczeń (w 2017 r. na poziomie jedynie 520 zł), rygorystycznych kryteriów dostępu do nich oraz uwarunkowania wsparcia pełną dezaktywizacją zawodową ${ }^{26}$. Wśród problemów, które składają się na trudną sytuację opiekunów, można także wymienić brak wsparcia wytchnieniowego, wsparcia szkoleniowego czy psychologicznego, co może zwiększać ryzyko wypalenia oraz utraty zdrowia fizycznego i psychicznego. Osobnym problemem jest sytuacja

20 Eurofound, Working and Caring: Reconciliation Measures in Times of Demographic Change, October 2015.

21 P. Łuczak, Opiekunowie dorosłych osób niepełnosprawnych w Polsce i ich aktywność zawodowa, „Polityka Społeczna” 2017, nr 8.

22 J. Stypińska, J. Perek-Białas, Working Careers in Poland - Successful Strategies of Reconciliation of Work and Care of an Adult, "Antropological Notebooks" 2014, Vol. 20, s. 87-103.

23 A. Furmańska-Maruszczak, Systemy wspierania aktywności zawodowej rodziny opiekunów osób starszych, „Polityka Społeczna” 2015, nr 7, s. 17-20.

${ }_{24}$ N. Marska-Dzioba, Świadczenia dla opiekunów w krajach Unii Europejskiej, Ubezpieczenia społeczne. Teoria i praktyka, „ZUS” 2015, nr 2(125).

25 R. Bakalarczyk, Polityka wsparcia rodzin z osobami niepetnosprawnymi. W cieniu wyroków Trybunału Konstytucyjnego RP i protestów społecznych, „Studia z Polityki Publicznej” 2015, nr 1(5).

26 Ibidem. 
niesamodzielnych seniorów, którym rodzina nie jest w stanie zapewnić opieki lub którzy podlegają osamotnieniu. Polski system opieki w typologiach porównawczych sytuuje się w grupie państw o mało hojnych i mało kompleksowych systemach opieki ${ }^{27}$, a w kontekście wsparcia opiekunów jako ten, w którym wsparcie w zakresie godzenia opieki z pracą zawodową jest słabo rozwinięte ${ }^{28}$.

Przyjrzyjmy się zatem, na ile kwestia ta w różnych jej aspektach i obliczach widziana jest przez instytucje polityki publicznej (zwłaszcza na poziomie centralnym, do którego odnosi się analiza) i jakie dokumenty bądź działania mogą o tym świadczyć.

\section{Miejsce opieki w Założeniach wieloletniej polityki senioralnej na lata 2014-2020}

Przegląd agendy zacznijmy od kluczowych dokumentów polityki publicznej, poczynając od wiodącego - Założeń wieloletniej polityki senioralnej na lata 2014-2020. Założenia zostały przygotowane przez Radę Polityki Senioralnej i przyjęte przez rząd w drodze uchwały. Dokument ten wprawdzie trudno uznać za strategię w ścisłym sensie, jako że nie zawiera ani dokładnego harmonogramu realizacji, ani źródeł finansowania, ani podmiotów odpowiedzialnych za przeprowadzanie i koordynowanie poszczególnych działań. Raczej widzieć go można jako założenia, które dopiero mogłyby być przekształcone w strategię (co w chwili pisania niniejszego artykułu nie doszło do skutku). Tym niemniej dokument ów określa horyzont myślenia o polityce senioralnej w pierwszym okresie jej realizacji i ramy działania (w których podjęto już pierwsze kroki, jak choćby omówiony dalej program Senior Wigor). W tym sensie Założenia są ważnym elementem agendy polityki senioralnej na poziomie systemowym i z tego względu warto im się przyjrzeć także pod kątem opiekuńczym. Zagadnienia bezpośrednio bądź pośrednio powiązane z opieką znajdują tu poczesne miejsce. W dokumencie tym bowiem dział "Zdrowie i samodzielność" pojawia się jako pierwszy z obszarów priorytetowych i poświęcono mu aż 15 na 50 stron raportu (nie licząc spisu tabel i wykresów ${ }^{29}$ ). W rozdziale tym jednak znajdujemy nie tylko rozdział pt. „Uwarunkowania rozwiązań medyczno-opiekuńczych” ale także „Bezpieczeństwo” i „Przestrzeń zamieszkania”. Pierwszy z podrozdziałów

27 M. Kraus, T. Czypionka, M. Riedel, E. Mot, P. Willeme, How European Nations Care for Their Elderly? A New Typology of Long-Term Care Systems, 2011.

28 Eurofound, Working and Caring: Reconciliation Measures in Times of Demographic Change, październik 2015.

29 Uchwała nr 238 Rady Ministrów z dnia 24 grudnia 2013 r. w sprawie przyjęcia dokumentu Założenia Długofalowej Polityki Senioralnej w Polsce na lata 2014-2020, http://www.monitorpolski.gov.pl/ $\mathrm{mp} / 2014 / 118 / 1$ 
jest jednak opisany najszerzej, najdokładniej oraz zawiera najbardziej rozbudowane rekomendacje, pogrupowane $w$ trzech priorytetach:

Priorytet 1. Stworzenie systemowych rozwiązań, które pozwolą na rozwój usług medycznych dla osób starszych.

Priorytet 2. Promocja zdrowia i profilaktyka zdrowotna.

Priorytet 3. Rozwój usług społecznych i opiekuńczych dostosowanych do potrzeb osób starszych ${ }^{30}$.

Choć w ścisłym sensie kwestii opiekuńczej dotyka ostatni z priorytetów, także dwa pozostałe pośrednio się do niej odnoszą.

Wskazanie priorytetów i przyporządkowanie im rekomendacji działań poprzedza część diagnostyczna, z której dowiadujemy się o (nie najlepszym) stanie zdrowia osób starszych, niezbyt zdrowym stylu życia już we wcześniejszych stadiach, deficytach kadrowych i infrastrukturalnych, jeśli chodzi o świadczenia zdrowotne (w tym te, których adresatami są właśnie osoby starsze). Następnie znajdujemy dwa podrozdziały, kolejno: „Opieka nad osobą starszą i rola opiekunów nieformalnych” oraz „Nowe technologie w opiece nad osobami starszymi”. W części diagnozy poświęconej opiece nad osobą starszą i roli opiekunów nieformalnych czytamy, że potrzeby opiekuńcze są znaczne i w związku ze starzeniem się społeczeństwa będą stanowiły coraz większe wyzwanie dla polityki senioralnej, jak i gospodarki. Znajdujemy także odwołanie do badań Eurobarometru, z których wynika, że rodzina jest preferowanym źródłem zapewnienia opieki osobom starszym, gdy popadają w zależność, zaś jedynie 8 proc. wskazuje jako preferowany model przychodzenie do osoby starszej opiekunów formalnych. W konkluzjach tego fragmentu czytamy zaś, że konieczne jest większe wsparcie opiekunów, w tym pozwalające na godzenie im opieki z pracą ${ }^{31}$. Z konkluzją tą trudno się nie zgodzić, choć mniej oczywiste jest, czy na przykład silne oparcie systemu opieki na rodzinie, jak dotychczas, to właściwa perspektywa. Sama część diagnostyczna w tym obszarze jest mało pogłębiona i bezpośrednio nie prowadzi do wniosków, które zostały sformułowane. Samo przywołane badanie, z którego wnioski te mają wynikać, prosi się o drobny komentarz. Badanie pochodzi sprzed ponad dekady, więc wyłaniający się z niego obraz społecznych przekonań i oczekiwań co do charakteru opieki nad osobami starszymi niekoniecznie musi być aktualny. Ponadto, jest dyskusyjne, czy ów rozkład preferencji na pewno powinien być zasadniczym drogowskazem dla przemian polityki senioralnej.

Relatywnie dużo miejsca poświęcono teleopiece i telemedycynie. Jest to niewątpliwie ważny obszar, choć można zastanawiać się, czy powinien on być tak silnie

\footnotetext{
30 Ibidem.

31 Ibidem.
} 
wyeksponowany w porównaniu z nieobecnymi w części diagnostycznej innymi od dawna rozpoznanymi i naglącymi problemami, jak np. niedobór wsparcia dziennego dla osób starszych o ograniczonej samodzielności, ograniczony dostęp do usług opiekuńczych i wspomagających w warunkach domowych czy rozmaite problemy segmentu opieki instytucjonalnej. Pomięcie tych zagadnień w części diagnozy jest kompensowane w części dotyczącej celów i odpowiadających im rekomendacji, z których możemy pośrednio wyczytać problemy uznane przez autorów dokumentu za ważne. W dziale tym sformułowano cztery cele:

Cel1. Rozwój usług społecznych dostosowanych do potrzeb oraz możliwości osób starszych.

Cel 2. Zapewnienie odpowiedniej opieki nad osobami o ograniczonej samodzielności poprzez rozwój usług opiekuńczych.

Cel 3. Opracowanie i wdrożenie systemu teleopieki oraz wykorzystanie innowacyjnych technologii w ułatwieniu organizacji opieki dla osób starszych.

Cel 4. Stworzenie systemów wsparcia dla opiekunów nieformalnych, w szczególności na poziomie lokalnym.

Do osiągnięcia celu nr 2 rekomendowane są: poprawa dostępu do usług opiekuńczych, co pozwoli osobom starszym i/lub o ograniczonej samodzielności jak najdłużej zostać we własnym środowisku; rozwój systemu świadczeń pieniężnych, w naturze lub czekach na pokrycie wydatków na usługi i produkty związane z opieką, w tym bardziej efektywna dystrybucja świadczeń poprzez ich dywersyfikację w zależności od stopnia ograniczenia samodzielności; tworzenie warunków do zwiększenia różnorodności form opieki nad seniorami: dzienne domy pomocy, opiekunowie dzienni, zorganizowana pomoc sąsiedzka, wspieranie rozwoju form samopomocowych, wolontariatu i innych, likwidacja barier legislacyjnych i administracyjnych w uregulowaniu zatrudnienia opiekunów nieformalnych; zmniejszenie udziału „szarej strefy” w rynku usług opiekuńczych; stworzenie warunków stabilnych źródeł finansowania usług opiekuńczych; lepsze dostosowanie obecnie dostępnych usług do potrzeb osób starszych, jak również rozwój nowych rozwiązań; zapewnienie wsparcia osobom starszym mieszkającym w jednoosobowych gospodarstwach domowych; identyfikacja osób potrzebujących wsparcia i opieki w gminie - systematyczny monitoring potrzeb w zakresie pomocy i opieki dla osób starszych oraz koordynowanie opieki we współpracy z lekarzem, pielęgniarką rodzinną i innymi podmiotami.

Ów wykaz faktycznie informuje o problemach do rozwiązania i mógłby się stać punktem wyjścia do skonstruowania precyzyjniejszych narzędzi działania. Podobnie jest w wypadku dwóch ostatnich celów opiekuńczych - teleoopieki i wsparcia opiekunów nieformalnych. 
W celu trzecim sugerowane są następujące kierunki interwencji - rekomendacje: opracowanie minimalnych standardów teleopieki i innych form niebezpośrednich usług opiekuńczych wykorzystujących nowe technologie (ICT); określenie źródeł i zasad finansowania lub dofinansowywania teleopieki i innych form niebezpośrednich usług opiekuńczych; aktywizacja środowisk lokalnych w celu tworzenia społecznych (sąsiedzkich) metod samopomocy przy wykorzystaniu nowych technologii (ICT); wspieranie wdrożenia rozwiązań z zastosowaniem teleopieki; wykorzystywanie nowych technologii dla rozwoju profilaktyki i zachowań prozdrowotnych ${ }^{32}$.

Z kolei w celu wsparcia rodziny i opiekunów nieformalnych w raporcie rekomendowane jest: opracowanie rozwiązań systemowych wspierających osoby opiekujące się osobami starszymi (umożliwiające łączenie pracy i opieki); stworzenie szerokiego dostępu do informacji o możliwościach wsparcia dla opiekunów oraz na temat możliwości poprawy jakości opieki przez opiekunów nieformalnych; umożliwienie opieki długo- i krótkotrwałej nad osobą starszą, na przykład w razie hospitalizacji opiekuna, lub opieki wytchnieniowej; rozwój wolontariatu opiekuńczego (w tym w sąsiedztwie, w środowisku lokalnym).

Choć od czasu sformułowania tej diagnozy, opartej zresztą na wiedzy, którą podmioty publiczne dysponowały znacznie wcześniej, minęło kilka lat, stan przekucia tych propozycji na konkretne działania finansowe i prawne na początku $2018 \mathrm{r}$. wydaje się niezadowalający. Nie został zrealizowany na większą skalę cel odnoszący się do teleopieki i telemedycyny, a także reformowanie systemu usług adresowanych do osób starszych przebiega w ograniczonym zakresie. Nie wypracowano również na poziomie systemowym konkretnych rozwiązań wsparcia o charakterze wytchnieniowym ani nie stworzono trwalszych podstaw do wykorzystania wolontariatu opiekuńczego, w tym sąsiedzkiego. Rekomendacje zawarte w Założeniach nie mówią też wprost o kwestiach wsparcia finansowego ani zabezpieczenia socjalnego opiekunów, choć w okresie przygotowania dokumentu problemy z tym związane musiały być już znane autorom. Można odnieść wrażenie, że przysparzająca trudności politycznych i prawnych sprawa opiekunów ubiegających się o dostępniejsze i wyższe wsparcie socjalne została w sposób intencjonalny - lub nie - pominięta w agendzie kształtującej się za pośrednictwem analizowanych tu Założeń.

\footnotetext{
32 Ibidem.
} 


\section{Opieka i niesamodzielność w założeniach Polityki społecznej wobec osób starszych do 2020 roku}

W chwili pisania niniejszego artykułu dokument mający zawierać rządową strategię polityki społecznej wobec osób starszych jest w fazie międzyresortowych konsultacji, więc trudno powiedzieć, jaki przyjmie ostateczny kształt. Ze wstępnego materiału, który udało się autorowi pozyskać, wynika jednak, że kwestia opiekuńcza jest obecna w myśleniu autorów dokumentu.

Strategia działań opiera się na podziale na działania wobec osób starszych ogółem oraz wobec osób starszych dotkniętych niesamodzielnością. Odniesienia do kwestii opiekuńczej znajdujemy przede wszystkim w tym drugim bloku. Wskazano w nim cztery priorytetowe obszary działań:

1. Zmniejszanie skali zależności od innych poprzez ułatwienie dostępu do usług wzmacniających samodzielność oraz dostosowanie środowiska zamieszkania do możliwości funkcjonalnych tych osób.

2. Zapewnienie dostępu do profesjonalnych usług zdrowotnych, rehabilitacyjnych i opiekuńczo-pielęgnacyjnych dostosowanych do potrzeb starszych osób niesamodzielnych.

3. Sieć usług środowiskowych i instytucjonalnych udzielanych starszym, niesamodzielnym osobom.

4. System wsparcia nieformalnych opiekunów niesamodzielnych osób starszych przez instytucje publiczne.

W dalszej części projektu dokumentu każdemu z priorytetów przyporząadkowane są konkretniejsze wytyczne (choć bez dokładnych wskaźników realizacji, terminarza czy skutków społecznych i finansowych). W zasadzie w każdym z czterech podpunktów możemy znaleźć odwołania do opieki długoterminowej i potrzeb osób jej wymagających. Trzy kluczowe wątki to działania na rzecz zmniejszenia niesamodzielności, dostęp do usług w różnej formie oraz wsparcie opiekunów. Dokładniejszy przegląd propozycji wskazuje, że autorzy kładą nacisk nie tylko na aspekty ilościowe (związane głównie z rozbudową różnych typów usług i form wsparcia oraz dostępem do nich dla niesamodzielnych osób starszych i ich bliskich), ale także jakościowe (związane ze standardami usług, podnoszeniem kompetencji po stronie opiekunów, sprawniejszymi strategiami komunikacyjnymi, zwłaszcza wobec osób z demencją, czy dotyczące modernizacji wsparcia w kierunku większego wykorzystania teleopieki i telemedycyny). Pewne elementy mogą jednak budzić niedosyt w zestawieniu z niektórymi obecnie artykułowanymi w przestrzeni publicznej problemami i postulatami. Przykładowo, w punkcie dotyczącym potrzeby wsparcia opiekunów, w katalogu zmian, 
jakie należy podjąć, pominięta została sprawa zabezpieczenia socjalno-bytowego tej grupy, choć to właśnie deficyty na tym polu są jednym z często podnoszonych przez samych zainteresowanych pilnych wyzwań. Nie znalazła się też bezpośrednia wzmianka o potrzebie umożliwienia godzenia pracy zawodowej z rolą opiekuna, choć i ta sprawa była w 2017 r. głośno i wielokrotnie podnoszona (np. w ramach społecznych petycji z inicjatywy „Chcemy całego życia”33 i projektu „Dom to praca” ${ }^{34}$ ). Kwestia ta była uwzględniona, chociaż nader ogólnie, w poprzednich założeniach „Polityki senioralnej...” z 2013 r. Nie jest zrozumiałe, dlaczego obecnie ten kierunek działań nie został wyszczególniony.

Patrząc całościowo na analizowany dokument można jednak powiedzieć, że kwestia opiekuńcza została w nim potraktowana poważnie, a jej wyodrębnienie jako jednego $\mathrm{z}$ dwóch zasadniczych działów planowanej polityki społecznej na rzecz osób starszych może świadczyć o wysokiej randze tej problematyki dla autorów dokumentu. Trudno jednak na obecnym etapie powiedzieć, czy, kiedy i w jaki sposób te założenia zostaną przełożone na konkretne propozycje, a tym bardziej kiedy zostaną wcielone w życie. Uwaga ta odnosi się w zasadzie do całego dokumentu.

\section{Program ASOS a kwestia opiekuńcza}

Konkretniejsze przełożenie na rzeczywistość społeczną ma jedna ze składowych tzw. pakietu senioralnego z 2013 r., mianowicie program ASOS. Jego pierwsza edycja na rok 2012/2013 poprzedziła wprowadzenie programu wieloletniego i wnioski z niej znalazły się w uchwale powołującej program na lata 2014-2020. Program polega na finansowym wsparciu w trybie konkursowym inicjatyw w czterech priorytetach. Z perspektywy potrzeb opiekuńczych interesujący jest szczególnie cel 4: Zwiększenie dostępności, podniesienie jakości usług społecznych oraz wspieranie działań na rzecz samopomocy i samoorganizacji; rozwój systemów wsparcia umożliwiających zaspokojenie specyficznych dla wieku podeszłego potrzeb, w szczególności osobom starszym o ograniczonej samodzielności; rozwój usług społecznych w sferze sportu, turystyki, rekreacji i kultury ${ }^{35}$. Pierwszy człon realizacji tego celu, czyli „rozwój systemów wsparcia umożliwiających zaspokojenie specyficznych dla wieku podeszłego potrzeb, w szczególności osobom starszym o ograniczonej samodzielności” wprost

33 https://chcemycalegozycia.pl/nasza-petycja-ruszyla/, dostęp 8.02.2018.

34 https://domtopraca.pl/zmien-prawo-pozwol-opiekunom-dorabiac/, dostęp 8.02.2018.

35 Uchwała nr 237 Rady Ministrów z dnia 24 grudnia 2013 r. w sprawie ustanowienia Rządowego Programu na rzecz Aktywności Społecznej Osób Starszych na lata 2014-2020, s. 11, http://www.monitorpolski.gov.pl/mp/2014/52/1 
łączy się z problematyką opieki długoterminowej i wsparcia osób niesamodzielnych i ich bliskich. Jeśli spojrzymy na wielkość środków, jakie w kolejnych corocznych edycjach programu przeznaczano w latach 2015-2016, widzimy, że aż 40 proc. całego budżetu programu przeznaczano właśnie na ów 4. priorytet. Organizacje społeczne w ramach 4. priorytetu składały oferty na trzy następujące kierunki działań:

- szkolenie dla wolontariuszy i opiekunów z zakresu pomocy osobom starszym, wspieranie różnych form samopomocy,

- wspieranie rodzin w opiece nad osobą starszą poprzez rozwój usług opartych na działalności wolontariuszy,

- rozszerzenie dostępności usług społecznych, m.in. opiekuńczych, kulturalnych, edukacyjnych, poradniczo-zdrowotnych, sportowych i turystycznych ${ }^{36}$.

Kierunki te wskazują na bliskość problematyki opieki długoterminowej, w tym wsparcia opiekunów. Jednak skala objęcia opiekunów programem jest ograniczona. Tryb konkursowy programu sprawia, że jego oddziaływanie nie ma charakteru systemowego, a dostęp dla seniorów i ich opiekunów jest uzależniony od lokalnych uwarunkowań (np. od tego, czy w danej społeczności funkcjonują organizacje pozarządowe, działające w obszarze senioralnym, i czy okażą się one skuteczne w pozyskiwaniu środków w ramach programu).

\section{Osoby wymagające opieki a Program Senior Wigor/Senior+}

Ważnym elementem prowadzonej polityki senioralnej jest program domów dla osób starszych typu Senior Wigor ${ }^{37}$, przemianowany po zmianie władzy na Senior $+{ }^{38}$. Program zakłada mechanizm finansowy wspierania powstawania domów dziennych dla osób starszych. W uchwale go powołującej czytamy, że stanowi on sposób realizacji III z priorytetów Założeń (Rozwój usług społecznych i opiekuńczych dostosowanych do potrzeb osób starszych).

Program zakłada dwa typy placówek: domy dzienne oraz kluby Senior+. Wsparcie finansowe realizowane jest $\mathrm{w}$ dwóch modułach: dofinansowania powstania nowych placówek i dofinansowania utrzymania miejsc w już istniejących placówkach.

36 MRPiPS, Sprawozdanie z realizacji Rządowego Programu na rzecz Aktywności Społecznej Osób Starszych na lata 2014-2020 - rok 2015, Warszawa 2016.

37 Uchwała nr 34 Rady Ministrów z dnia 17 marca 2015 r. w sprawie ustanowienia programu wieloletniego Senior Wigor na lata 2015-2020, http://www.monitorpolski.gov.pl/mp/2015/341

38 Uchwała nr 157 Rady Ministrów z dnia 20 grudnia 2016 r. zmieniająca uchwałę w sprawie ustanowienia programu wieloletniego Senior Wigor na lata 2015-2020, http://www.monitorpolski.gov.pl/ $\mathrm{mp} / 2016 / 1254 / 1$ 
Samorządy ubiegające się o wsparcie muszą spełnić określone warunki, jak wkład własny czy zobowiązanie do prowadzenia placówek przez określony czas.

Pytanie, jakie nasuwa się w kontekście prowadzonych tu rozważań dotyczy tego, na ile program pozwala zaspokajać potrzeby opiekuńcze lub rozwiązywać problemy składające się na kwestię opiekuńczą. Ocena nie jest jednoznaczna. Z jednej strony uchwała wspomina o potrzebach opiekuńczych, z drugiej stron ramy funkcjonowania placówek przewidzianych w niej, jak również wymieniony w uchwale katalog usług w nich świadczonych, nie dają twardych podstaw do powiązania ich $\mathrm{z}$ tematyką ściśle opiekuńczą ani potrzebami i możliwościami osób wymagających stałej, długoterminowej opieki.

Zgodnie z uchwałą podstawowy zakres usług świadczonych przez Dzienny Dom „Senior Wigor może obejmować w szczególności usługi: socjalne, w tym posiłek; edukacyjne; kulturalno-oświatowe; aktywności ruchowej lub kinezyterapii; sportowo-rekreacyjne; aktywizujące społecznie (w tym wolontariat międzypokoleniowy; terapii zajęciowej) $)^{39}$. Opieka nie tylko nie pojawia się expressis verbis, ale brak również w powyższym katalogu usług związanych czy to z pielęgnacją, czy rehabilitacją.

Nowe regulacje, które wprowadzono na mocy uchwały z 20 grudnia 2016 r., nie przyniosły zmiany w zasadniczym profilu placówek, na których powstawanie lub utrzymanie w nich dotychczasowych miejsc samorządy mogą otrzymywać dofinansowanie ${ }^{40}$. Nadal zarówno wyszczególnione funkcje, jak i opis minimalnych standardów nie wskazują na uwzględnienie specyfiki potrzeb o znacznych ograniczeniach samodzielności. Tym samym program, bez względu na korzyści, jakie niesie dla jego odbiorców, powiela pewne już istniejące deficyty w infrastrukturze wsparcia dziennego seniorów zależnych od opieki i ich bliskich. Na tego rodzaju deficyty wskazuje choćby badanie przygotowane przez Małopolskie Obserwatorium Polityki Społecznej pt. „Opiekunowie rodzinni osób starszych - problemy, potrzeby, wyzwania dla polityki społecznej” ${ }^{41}$. W części raportu z badania prezentującego wypowiedzi ekspertów znajdujemy opinię, że dotychczasowe ośrodki dzienne raczej są dostosowane do potrzeb osób starszych o ograniczonym ubytku sprawności, ale już nie dla osób głęboko niesamodzielnych. Teoretycznie można przyjąć, że taki stan rzeczy dałoby się uzasadnić założeniem, że wsparcie $w$ trybie dziennym jest przeznaczone dla osób mniej samodzielnych, podczas gdy osoby wymagające intensywniejszej czy po prostu stałej opieki powinny być kierowane do placówek całodobowych/stacjonarnych. Taka interpretacja nie pojawia się wprawdzie w rządowych

39 Uchwała nr 34, op.cit.

40 Uchwała nr 157, op.cit.

41 M. Szlązak, A. Piłat, J. Sarata, Opiekunowie rodzinni osób starszych-problemy, potrzeby, wyzwania dla polityki społecznej. Raport z badania, Regionalny Ośrodek Polityki Społecznej, Kraków 2015. 
dokumentach, więc trudno powiedzieć, czy za istniejącym stanem rzeczy stoi właśnie takie podejście. Tym niemniej można wobec stanu instytucjonalnego, który takie podejście w sposób intencjonalny bądź nieintencjonalny wyraża, sformułować dwa rodzaje obiekcji. Osoby znacznie niesamodzielne nie zawsze trafiają do placówek stacjonarnych, a często pozostają w warunkach domowych wraz z ich rodzinnym/ nieformalnym opiekunem. Możliwość skorzystania z innej opieki przez podopiecznych przez kilka godzin w ciągu dnia mogłaby pełnić dla nich funkcje wytchnieniowe, czasowo odciążające ich w roli opiekunów. Po drugie, wiele działań o charakterze rehabilitacyjno-medycznym wobec osób znacznie niesamodzielnych trudno przeprowadzić jest $\mathrm{w}$ warunkach domowych (choćby $\mathrm{z}$ uwagi na ograniczenia sprzętowe czy ograniczone kompetencje opiekuna rodzinnego w tym zakresie), a można by je realizować właśnie w placówkach o charakterze dziennym. Po trzecie, osoba nawet o znacznej niesamodzielności również powinna być traktowana jako podmiot praw, na które składa się także perspektywa społecznego uczestnictwa i integracji z szerszym otoczeniem. Ośrodki działające w trybie dziennym mogą tę funkcję pełnić, czasowo wyciągając takie osoby z czterech ścian otoczenia domowego. Po czwarte, dla opiekunów, którzy chcieliby choćby w ograniczonym wymiarze kontynuować lub podjąć pracę, miejsca w placówkach dziennej opieki dla ich podopiecznych mogłyby być czynnikiem umożliwiającym realizację tych aspiracji.

Podsumowując, istnieje wiele przesłanek skierowania oferty placówek wsparcia dziennego do osób znacznie niepełnosprawnych, wymagających stałej, długoterminowej opieki. Przesłanki te odwołują się do dobra zarówno samej niesamodzielnej osoby starszej, jak i jej bliskich. W tym sensie usunięcie istniejących ograniczeń byłoby krokiem do budowy lepszego systemu wsparcia opiekunów nieformalnych (o czym mówi cel 4 III priorytetu Założeń). Program w pierwszych latach obowiązywania, także po modyfikacjach towarzyszących przemianowaniu go na Senior+, nie osiąga tego celu w satysfakcjonującym stopniu, a jednocześnie w ramach pozostałej części infrastruktury wsparcia brakuje działań o charakterze systemowym, które ową lukę by wypełniały. Problem tu omówiony wydaje się słabą stroną dotychczasowej polityki senioralnej i jej agendy.

\section{Program Opieka 75+}

Nowym, z przełomu 2017 i 2018 r., elementem polityki senioralnej jest program Opieka 75+, mogący sugerować położenie większego nacisku na kwestie opiekuńcze w polityce rządu niż dotychczas. Program zakłada resortowe dofinansowanie w trybie konkursowym dla zwiększenia wymiaru usług opiekuńczych i specjalistycznych usług 
opiekuńczych w małych gminach (poniżej 20 tys. mieszkańców). Dofinansowanie może zostać przekazane „na zwiększenie liczby godzin usług opiekuńczych lub specjalistycznych usług opiekuńczych dla osób, które już korzystają z takich usług (lub korzystały z nich w ostatnim roku) lub „na dofinansowanie usług opiekuńczych lub specjalistycznych usług opiekuńczych dla osób, które dotychczas ich nie otrzymywały" ${ }^{42}$. Warunkiem było jednak zatrudnienie na podstawie umowy o pracę osób świadczących te usługi (co dla części gmin okazało się barierą) będących pracownikami/pracownicami ośrodków pomocy społecznej, urzędów gmin lub innych gminnych jednostek organizacyjnych, a także wniesienie wkładu własnego zadania na poziomie przynajmniej 50 proc. $^{43}$.

W pierwszej edycji programu, do którego nabór zakończył się 20 stycznia 2018 r., wpłynęły do urzędów wojewódzkich wnioski z 485 gmin (spośród 2140 uprawnionych ze względu na liczbę mieszkańców) ${ }^{44}$. Na cały rok 2018 przewidziano 57,4 mln zł. Program jako narzędzie do złagodzenia deficytów w dostępie do opieki w warunkach domowych wydaje się w istniejących ramach finansowych i prawnych dość ograniczony. Oprócz relatywnie skromnej puli środków, z których jedynie część zostanie wydana $z$ uwagi na niewielką liczbę zgłoszeń, istnieją dwa zasadnicze ograniczenia. Po pierwsze, końcowymi beneficjentami mogą być jedynie osoby powyżej 75. roku życia, a tymczasem potrzeby opiekuńcze (w tym te wymagające usług o charakterze specjalistycznym) mogą dotknąć jednostkę we wcześniejszych fazach starości (i ogólnie wcześniejszych fazach życia). Ponadto zakres oddziaływania jest ograniczony jedynie do małych gmin. Choć istotnie, $w$ świetle diagnozy poprzedzającej wprowadzenie programu, właśnie w tych gminach najtrudniej jest zapewnić odpowiedni zakres usług domowych (zwłaszcza tych specjalistycznych), problemy tego rodzaju dotykają w mniejszym lub większym stopniu także nieco większe gminy.

Mimo tych zastrzeżeń, zainicjowanie programu Opieka 75+ stanowi wzmocnienie polityki senioralnej w wymiarze opiekuńczym. Trudno powiedzieć, czy program będzie rozwijany i w jaki sposób w kolejnych latach.

${ }^{42}$ https://das.mpips.gov.pl/source/opiekasenioralna/Program\%20Opieka\%2075\%20 w\%20pigulce. pdf

43 Ibidem.

44 M. Topolewska, Mało chętnych na dotację z programu Opieka 75+, „Dziennik Gazeta Prawna”, 1 lutego 2018, s. B7. 


\section{Kwestia opiekuńcza w świetle działalności Najwyższej Izby Kontroli}

Przyjrzyjmy się teraz temu, jakim zainteresowaniem kwestia opiekuńcza lub jej poszczególne aspekty cieszyły się wśród wybranych centralnych instytucji publicznych. Najwyższa Izba Kontroli to instytucja, która w drugiej dekadzie XXI w. podejmowała niejednokrotnie działania kontrolne właśnie w obszarze związanym z opieką długoterminową. Kontrolą objęte były instytucje i działania w różnych segmentach systemu opieki. Na przełomie dekady zaprezentowano raporty pokontrolne w dwóch typach instytucji opieki instytucjonalnej: „Informacja o wynikach kontroli kierowania osób do domów pomocy społecznej i finansowania ich pobytu przez organy samorządu terytorialnego” 45 oraz „Informacja o wynikach kontroli funkcjonowania zakładów opiekuńczo-leczniczych" ${ }^{36}$ z marca 2010 r. pokazujące - zwłaszcza w wypadku drugiej kontroli - druzgocący obraz tego segmentu opieki i nieprawidłowości na wielu polach. Zainteresowanie problematyką opiekuńczą, choć w nieco szerszym wymiarze, niesprowadzonym do opieki instytucjonalnej, ze strony Najwyższej Izby Kontroli przyniosły ostatnie lata 2016-2017. Wydane zostały wówczas trzy ważne, dostępne na stronie NIK, raporty:

- „O świadczeniu pomocy osobom starszym przez gminy i powiaty” z lutego $2016 \mathrm{r}^{47}$,

- „Opieka nad chorymi na Alzheimera i wsparcie ich rodzin” z kwietnia 2017 r. $^{48}$,

- „Opieka nad osobami starszymi w dziennych domach pomocy” z czerwca 2017 r. ${ }^{49}$. Wszystkie te trzy dokumenty składają się na wielowymiarowy i pogłębiony obraz aktualnych problemów w polityce wsparcia wobec wymagających opieki lub wsparcia osób starszych i ich rodzin. Wskazują one na znaczne deficyty w infrastrukturze opieki, zwłaszcza w trybie dziennym. Raporty te oprócz diagnozy zawierają też cenne, konkretne rekomendacje dla różnych podmiotów polityki publicznej na różnych szczeblach administracyjnych, poczynając od szczebla centralnego.

45 Najwyższa Izba Kontroli, Informacja o wynikach kontroli kierowania osób do domów pomocy społecznej i finansowania ich pobytu przez organy samorządu terytorialnego.

46 Najwyższa Izba Kontroli, Informacja o wynikach kontroli funkcjonowania zakładów opiekuńczo-leczniczych, marzec 2010.

47 Najwyższa Izba Kontroli, Informacja o wynikach kontroli „Świadczenie pomocy osobom starszym przez gminy i powiaty", Warszawa, luty 2016.

48 Najwyższa Izba Kontroli, Informacja o wynikach kontroli „Opieka nad osobami chorymi na chorobę Azlheimera oraz wsparcie dla ich rodzin”, Warszawa, kwiecień 2017.

49 Najwyższa Izba Kontroli, Informacja o wynikach kontroli „Opieka nad osobami starszymi w dziennych domach pomocy", maj 2017. 


\section{Kwestia opiekuńcza w działalności Rzecznika Praw Obywatelskich}

Ważną rolę w kształtowaniu agendy polityki senioralnej, także w kontekście opiekuńczym, odgrywa od lat Rzecznik Praw Obywatelskich, a rola ta była widoczna jeszcze zanim polityka senioralna została w polskiej polityce publicznej wyodrębniona. Świadczą o tym liczne raporty, organizowane seminaria, a także wystąpienia do organów publicznych w ramach rzecznictwa praw osób, które w sferach powiązanych z opieką bywały zagrożone czy wręcz łamane. Jeśli chodzi o raporty, należy wskazać wiele opracowań zbiorowych dotyczących osób starszych, ich praw i wsparcia. Można wymienić choćby raport „Stan przestrzegania praw osób starszych w Polsce” (z 2009 r. za kadencji J. Kochanowskiego), „Strategie działania w starzejącym się społeczeństwie ${ }^{51}$ (z 2012 r. za kadencji I. Lipowicz) czy „System wsparcia środowiskowego osób starszych" ${ }^{\prime 2}$. Wszystkie te publikacje w mniejszym lub większym zakresie poruszały także problematykę opieki długoterminowej i zależności od niej części osób starszych. W pierwszych dwóch spośród wymienionych publikacji potrzeby opiekuńcze były wyodrębnione w postaci osobnych rozdziałów (przygotowanych przez P. Błędowskiego), zaś w ostatniej publikacji zagadnienia opiekuńcze są integralną częścią problematyki wsparcia środowiskowego, któremu całe opracowanie (zawierające też część badawczą) jest poświęcone. Rzecznik w swojej działalności zwracał niejednokrotnie uwagę na poszczególne grupy osób starszych wymagających szczególnie intensywnej opieki, jak osoby cierpiące na chorobę Alzheimera. Wyrazem troski o tę grupę jest raport „Sytuacja osób chorych na chorobę Alzheimera” ${ }^{3}$.

Wśród licznych działań interwencyjnych Rzecznika w obszarze opieki warto szczególnie podkreślić te, które odnoszą się do praw nieformalnych/rodzinnych opiekunów osób niepełnosprawnych (zwłaszcza dorosłych). W tym obszarze mieliśmy do czynienia ze szczególnie dotkliwym i uporczywym łamaniem konstytucyjnych praw części osób zaangażowanych w opiekę (świadczą o tym liczne wyroki Trybunału Konstytucyjnego, orzekające niezgodność z ustawą zasadniczą niektórych zapisów ustawy o świadczeniach rodzinnych, regulującej dostęp do świadczeń dla tej kategorii

50 Stan przestrzegania praw osób starszych. Analiza i rekomendacje działań, Raport RPO, red. B. Szatur-Jaworska, Warszawa 2008, s. 69-79 i 142-144.

51 Strategie działania w starzejącym się społeczeństwie. Tezy i rekomendacje. Raport RPO, red. B. Szatur-Jaworska, Warszawa 2012, rozdział: P. Błędowski, Zaspokojenie potrzeb opiekuńczych osób starszych, s. $55-62$.

52 Sytuacja wsparcia osób starszych w środowisku zamieszkania. Przegląd sytuacji, propozycja modelu, Raport RPO, red. P. Błędowski, B. Szatur-Jaworska, Warszawa 2016.

53 Sytuacja osób chorych na chorobę Alzheimera, red., A. Szczudlik, Warszawa, maj 2014. 
osób $)^{54}$. Rzecznik w swoich wystąpieniach wielokrotnie przypominał o istniejących problemach, a także upominał ustawodawcę z powodu długotrwałego niewykonywania orzeczeń Trybunału Konstytucyjnego w kwestii zmian w regulacjach dotyczących opiekunów. Szczególne przełożenie praktyczne miał złożony przez biuro Rzecznika Praw Obywatelskich wniosek do Trybunału Konstytucyjnego z lipca $2013 \mathrm{r} .{ }^{55} \mathrm{w}$ sprawie utraty prawa do świadczenia ze strony bardzo licznej grupy opiekunów niepełnosprawnych osób dorosłych. Pozytywne rozpatrzenie tego wniosku i wydanie 5 grudnia 2013 r. ${ }^{56}$ wyroku nakazującego przywrócenie praw poszkodowanym zaowocowało rychłym przyjęciem rozwiązań ustawowych, na mocy których część wykluczonych ze wsparcia opiekunów nabyło prawo do zastępczego wsparcia pieniężnego w związku ze sprawowaną opieką. Czujność i aktywność Rzecznika Praw Obywatelskich na tym polu, a także w dziedzinach pokrewnych, nie wygasła po realizacji wspomnianego wyroku, a Rzecznik, niezależnie od zmiany osoby pełniącej ów urząd, nadal wykazuje konsekwentne zaangażowanie w nagłaśnianiu problemów tej grupy i zobowiązań ciążących na władzy publicznej.

\section{Krajowy mechanizm prewencji a opieka instytucjonalna}

Na osobne potraktowanie zasługuje też dokument przyjęty w ramach krajowego mechanizmu prewencji, nad którym pieczę powierzono także Rzecznikowi Praw Obywatelskich. Chodzi o raport z 2017 r. pt. „Prawa mieszkańców domów pomocy społecznej. Jak wspólnie zadbać o godne życie osób starszych, chorych i z niepełnosprawnościami? Z działalności RPO w ramach krajowego mechanizmu prewencji tortur" ${ }^{\prime 2}$.

W ramach kontroli w placówkach opieki instytucjonalnej zdiagnozowano i szczegółowo opisano wiele problemów: brak systemu kontroli legalności pobytu osób skierowanych do domu pomocy społecznej orzeczeniem sądowym; powiązany z tym problem niedostatecznej kontroli sprawowanej w domach pomocy społecznej przez sędziów rodzinnych, ograniczone kontakty ze światem zewnętrznym mieszkańców

\footnotetext{
54 R. Bakalarczyk..., op.cit.

55 Rzecznik Praw Obywatelskich, Wniosek Rzecznika Praw Obywatelskich do Trybunału Konstytucyjnego, Warszawa 24 czerwca 2013 r.

56 Wyrok Trybunału Konstytucyjnego z dnia 5 grudnia 2013 r., sygn. akt K 27/13. Uzasadnienie, http:// ipo.trybunal.gov.pl/ipo/ Sprawa?sprawa=11859\&dokument=9993\&cid=1\#uzasadnienia_czesc_9993_III dostęp 30.03.3016.

57 Rzecznik Praw Obywatelskich, Prawa mieszkańców domów pomocy społecznej. Jak wspólnie zadbać o godne życie osób starszych, chorych i z niepełnosprawnościami? Raport z działalności RPO krajowego mechanizmu prewencji tortur, Warszawa 2017.
} 
DPS-ów, zapewnienie pensjonariuszom odpowiedniej opieki psychologiczno-psychiatrycznej, organizacja pomieszczeń do stosowania przymusu bezpośredniego, nadużywanie alkoholu przez część mieszkańców placówek, stosowanie tzw. monitoringu wizyjnego czy problemy osób ubezwłasnowolnionych ${ }^{58}$. Wśród obszarów wymagających zdaniem autorów raportu naprawy znalazły się takie zagadnienia jak: kierowanie i pobyt $\mathrm{w}$ domach pomocy społecznej, traktowanie mieszkańców przez personel domów pomocy społecznej, prawo do opieki zdrowotnej, dokumentowanie przymusu bezpośredniego oraz dyscyplinowanie mieszkańców i ich prawo do informacji ${ }^{59}$. Wskazano także rekomendacje dla Ministerstwa Pracy i Polityki Społecznej, jak również dla Ministerstwa Zdrowia ${ }^{60}$. Wydaje się, że szczegółowość diagnozy w tak newralgicznych aspektach funkcjonowania domów pomocy społecznej może stanowić ważny punkt odniesienia dla rozwoju agendy publicznej polityki senioralnej na odcinku opieki instytucjonalnej.

\section{Badanie UOKiK jako fragment agendy polityki senioralnej}

Jeśli chodzi o kontrolę publiczną tego, co dzieje się w prywatnym sektorze opieki, należy wspomnieć o badaniu, które przeprowadził Urząd Ochrony Konkurencji i Konsumenta pt. „Domy opieki. Badanie wzorców umownych stosowanych w placówkach świadczących usługi w zakresie zapewnienia opieki osobom niepełnosprawnym, przewlekle chorym lub osobom w podeszłym wieku" z $2014 \mathrm{r}^{6}{ }^{61}$. Badanie było prowadzone od 2014 r. na terenie całego kraju, obejmując swoim zasięgiem 72 przedsiębiorców i 180 umów. Okazało się, że aż 90 proc. z nich wzbudziło zastrzeżenia. Wśród powtarzających się nieprawidłowości, łamiących przepisy prawa, a także uderzających w interes podopiecznych, zidentyfikowano następujące uchybienia: możliwość rozwiązania umowy ze skutkiem natychmiastowym (86 proc. przypadków) niezwracanie pieniędzy w razie niezrealizowania usługi (61 proc.), zmiany ceny usługi bez zgody konsumenta (51 proc.), wyłączenie odpowiedzialności za szkody na osobie (20 proc.) i wygórowane kary umowne lub odsetki (17 proc.). ${ }^{62}$. Skala nieprawidłowości w tak delikatnej sferze, jaką jest opieka nad osobami niepełnosprawnymi, chorymi i starszymi pokazuje kolejny wymiar kwestii opiekuńczej w Polsce i konieczność

58 Ibidem, s. 61-94.

59 Ibidem, s. 98-122.

60 Ibidem, s. 126-128.

61 UOKiK, Domy opieki. Badanie wzorców umownych stosowanych w placówkach świadczących ustugi w zakresie zapewnienia opieki osobom niepetnosprawnym, przewlekle chorym lub osobom w podesztym wieku, Warszawa 2014.

62 Ibidem. 
nadzoru publicznego nad działalnością tego sektora. Naświetlenie problemu przez UOKiK stanowi asumpt do podjęcia działań publicznych. Za jedno z nich można uznać prowadzoną przez MRPiPS kampanię „Aktywny i Bezpieczny Senior”63, której częścią jest uświadomienie osób starszych i ich bliskich w sprawie zagrożeń, jakie czyhają na nich w kontaktach z podmiotami świadczącymi długoterminową opiekę. Warto podkreślić, że UOKiK nie ograniczył się tylko do zdiagnozowania problemu, ale wszczął 15 postępowań wyjaśniających oraz skierował prawie 80 wystąpień do przedsiębiorców, wzywając ich do zmiany wadliwych umów. Jak podaje Urząd, większość zakwestionowanych postępowań zostało wyeliminowanych. Wydaje się, że działania te uzasadniają podjęcie potraktowania inicjatywy UOKiK jako składowej agendy polityki senioralnej w kontekście opiekuńczym.

\section{Zestawienie działań polityki publicznej odnoszących się do kwestii opiekuńczej}

Zgodnie z zaproponowanym wyżej podziałem, możliwe jest wskazanie działań bezpośrednio realizowanych przez rząd, a konkretnie działający przy Ministerstwie Rodziny, Pracy i Polityki Rodzinnej Departament Polityki Senioralnej wraz z działającą przy nim Radą Polityki Senioralnej, z drugiej zaś strony innych podmiotów, których działania mają charakter głównie kontrolny i rzeczniczy. W pierwszej kategorii (tabela 1) znalazły się zarówno działania polegające na przyjmowaniu dokumentów o charakterze strategicznym, a mówiąc ściślej założeń dla strategii w obszarze senioralnym, jak i realnie działające programy, np. ASOS, Senior Wigor/Senior+, a ostatnio także Opieka 75+. Jeśli chodzi o aktywność innych podmiotów (zestawioną w tabeli 2), działalność w obszarze opieki koncentruje się przede wszystkim na przeprowadzeniu badań kontrolnych i na tej podstawie prezentowanie rekomendacji, jak również w wypadku RPO na działaniach interwencyjnych i rzeczniczych w sferach, w których prawa starszych osób dotkniętych niesamodzielnością i/lub ich opiekunów są zagrożone.

63 Senior.gov.pl, zakładka poświęcona kampanii „Bezpieczny i aktywny senior”, http://senior.gov.pl/ bezpieczny_i_aktywny_senior/strona/76 
Tabela 1. Działania po stronie rządu w kontekście opiekuńczym

\begin{tabular}{|c|c|c|}
\hline $\begin{array}{l}\text { Podmiot polityki } \\
\text { publicznej }\end{array}$ & $\begin{array}{l}\text { Działanie, w którym znajdujemy odniesienie } \\
\text { do kwestii opiekuńczej }\end{array}$ & $\begin{array}{l}\text { Problemy opiekuńcze, do których odnoszą się } \\
\text { wskazane działania }\end{array}$ \\
\hline $\begin{array}{l}\text { Departament polityki } \\
\text { senioralnej (MRPiPS) }\end{array}$ & $\begin{array}{l}\text { Program ASOS, priorytet IV } \\
\text { Program Senior + (wcześniej Senior Wigor), } \\
\text { moduł „dzienne domy” } \\
\text { Program Opieka } 75+\end{array}$ & $\begin{array}{l}\text { Potrzeba wsparcia o charakterze usługowym } \\
\text { seniorów i ich opiekunów } \\
\text { Potrzeba wsparcia w ośrodkach działających } \\
\text { w trybie dziennym } \\
\text { Potrzeba wsparcia w codziennym } \\
\text { funkcjonowaniu w warunkach domowych, } \\
\text { problem dostępu do usług opiekuńczych } \\
\text { i specjalistycznych usług opiekuńczych, } \\
\text { zwłaszcza w małych gminach }\end{array}$ \\
\hline $\begin{array}{l}\text { Rada ds. polityki } \\
\text { senioralnej działająca } \\
\text { przy departamencie } \\
\text { polityki senioralnej } \\
\text { (MRPiPS) }\end{array}$ & $\begin{array}{l}\text { „Założenia Polityki Senioralnej na lata } \\
\text { 2014-2020” z grudnia } 2013 \text { roku, } \\
\text { Przede wszystkim Priorytet II - Rozwój usług } \\
\text { społecznych i opiekuńczych dostosowanych } \\
\text { do potrzeb osób starszych } \\
\text { "Polityka społeczna wobec osób starszych } \\
\text { do 2030" (wstępne założenia dostępne } \\
\text { na początku } 2018 \text { roku) }\end{array}$ & $\begin{array}{l}\text { Różne problemy związane z opieką } \\
\text { i niesamodzielnością, m.in: } \\
\text { - potrzeba rozwoju teleopieki i telemedycyny, } \\
\text { - potrzeba wsparcia opiekunów, } \\
\text { - potrzeba rozwoju wsparcia dziennego } \\
\text { i środowiskowego } \\
\text { Różne problemy związane z opieką } \\
\text { i niesamodzielnością w starszym wieku } \\
\text { uznane za wyzwania strategiczne, m.in. } \\
\text { wsparcie opiekunów } \\
\text { Różne zagadnienia związane z opieką } \\
\text { i niesamodzielnością, m.in.: } \\
\text { - potrzeba działań zwiększających } \\
\text { - samodzielność osób w starszym wieku } \\
\text { - potrzeba rozbudowy sieci instytucji } \\
\text { wspomagających osoby starsze dotknięte } \\
\text { niesamodzielnością } \\
\text { - wsparcie opiekunów }\end{array}$ \\
\hline
\end{tabular}

Źródło: opracowanie własne na podstawie analizy dokumentów omówionych w artykule.

Tabela 2. Działania po stronie innych podmiotów polityki publicznej w kontekście opiekuńczym

\begin{tabular}{|c|c|c|}
\hline $\begin{array}{c}\text { Organ polityki } \\
\text { publicznej }\end{array}$ & & \\
\hline $\begin{array}{l}\text { Najwyższa Izba } \\
\text { Kontroli }\end{array}$ & $\begin{array}{l}\text { Raporty kontrolne dotyczące opieki } \\
\text { i niesamodzielności w starszym wieku, m.in.: } \\
\text { • „O świadczeniu pomocy osobom starszym } \\
\text { przez gminy i powiaty” z lutego } 2016 \text { r. } \\
\text { • "Opieka nad chorymi na Alzheimera } \\
\text { i wsparcie ich rodzin” z kwietnia } 2017 \text { r. } \\
\text { • "Opieka nad osobami starszymi } \\
\text { w dziennych domach pomocy” z czerwca } \\
2017 \text { r. }\end{array}$ & $\begin{array}{l}\text { Trudna sytuacja osób z chorobą Alzheimera } \\
\text { i deficyt wsparcia dla ich rodzin } \\
\text { Ograniczony dostęp do opieki i wsparcia } \\
\text { w ramach ośrodków działających w trybie } \\
\text { dziennym } \\
\text { Różne problemy ze wsparciem (także } \\
\text { opiekuńczym) wobec osób starszych } \\
\text { na poziomie lokalnym np.: } \\
\text { - rosnące koszty opieki instytucjonalnej } \\
\text { - niedobór alternatywnych form opieki } \\
\text { i wsparcia } \\
\text { - słabe uwzględnienie problematyki osób } \\
\text { starszych w gminnych strategiach } \\
\text { rozwiązywania problemów społecznych }\end{array}$ \\
\hline
\end{tabular}




\begin{tabular}{|c|c|c|}
\hline $\begin{array}{c}\text { Organ polityki } \\
\text { publicznej }\end{array}$ & & \\
\hline $\begin{array}{l}\text { Rzecznik Praw } \\
\text { Obywatelskich }\end{array}$ & $\begin{array}{l}\text { - Liczne interwencje w sprawie opiekunów } \\
\text { osób niesamodzielnych } \\
\text { - Raporty i konferencje, np. raport o sytuacji } \\
\text { osób z chorobą Alzheimera } \\
\text { - Raporty przekrojowe, poświęcone } \\
\text { wyzwaniom starzejącego się } \\
\text { społeczeństwa i prawom osób starszych } \\
\text { - Działania w ramach Krajowego } \\
\text { Mechanizmu Prewencji }\end{array}$ & $\begin{array}{l}\text { - Problem nierównego dostępu do } \\
\text { świadczeń pieniężnych z tytułu opieki nad } \\
\text { niesamodzielnymi bliskimi } \\
\text { - Trudna sytuacja osób z chorobą } \\
\text { Alzheimera } \\
\text { - Różne problemy z zapewnieniem opieki } \\
\text { i wsparcia i respektowaniem praw osób } \\
\text { starszych w ramach ogólniejszego } \\
\text { wyzwania, jakie towarzyszy starzeniu się } \\
\text { społeczeństwa } \\
\text { - Zagrożenia dla praw osób przebywających } \\
\text { w placówkach opieki instytucjonalnej }\end{array}$ \\
\hline UOKiK & $\begin{array}{l}\text { Badanie kontrolne sprawdzające treść umów } \\
\text { między prywatnymi instytucjami opieki } \\
\text { a osobami starszymi }\end{array}$ & $\begin{array}{l}\text { Problemy prywatnego rynku opieki } \\
\text { i nieprawidłowości w zawieranych umowach } \\
\text { między instytucjami świadczącymi opiekę } \\
\text { a seniorami lub ich bliskimi }\end{array}$ \\
\hline
\end{tabular}

Źródło: opracowanie własne na podstawie wcześniejszej analizy dokumentów omówionych w artykule.

Analiza przyjętych dokumentów i działań prowadzi do wniosku, że kwestia opiekuńcza jest ważnym zagadnieniem w dotychczasowej agendzie polityki senioralnej, chociaż przełożenie działań na regulacje prawne skutecznie zmieniające sytuację osób starszych, zależnych od opieki i podmiotów ją świadczących, bywa ograniczone. Problematyka opieki długoterminowej jest mocno wyeksponowana w strategicznych Założeniach polityki senioralnej na lata 2014-2020 i obecnie przygotowywanej Polityki Społecznej wobec osób starszych do 2030 roku. Ograniczeniem ich oddziaływania są status i charakter dokumentów sprawiający, że stanowią one raczej założenia niż gotową strategię (choć drugi ze wskazanych dokumentów ma szanse niebawem zostać rozwinięty i skonkretyzowany). Można także sformułować konkretniejsze zastrzeżenia odnośnie do tego, jak problemy opiekuńcze są zdiagnozowane i na ile trafne i precyzyjne są rekomendacje w każdym z dotychczas przedstawionych. Działające programy ASOS i Senior Wigor/Senior+ dotykają również problemów opieki, chociaż dokładniejsze przyjrzenie się ich konstrukcji prawnej i realizacji wskazuje, że ich oddziaływanie na osoby starsze wymagające opieki, zwłaszcza intensywnej, oraz ich bliskich, jest ograniczone. W wypadku programu ASOS ograniczenie wiąże się ze skalą programu i środków przeznaczonych w ramach czwartego priorytetu częściowo odnoszącego się do potrzeb opiekuńczych. W wypadku programu Senior Wigor/ Senior+ problem jest bardziej fundamentalnej natury i wiąże się z niedostosowaniem formuły wsparcia do potrzeb oraz możliwości osób głęboko zależnych i ich bliskich. Nadzieję na dalszy rozwój systemowej polityki wsparcia daje przyjęty na przełomie 
2017 i 2018 r. program Opieka 75+, choć w punkcie wyjścia zakres oddziaływania jest finansowo $(56,4 \mathrm{mln}$ przewidziane na $2018 \mathrm{r}$.) i podmiotowo (osoby w wieku 75+, mieszkańcy tylko małych gmin) dość mocno ograniczony.

Na uwagę zasługuje aktywność innych instytucji publicznych, które rozmaitym problemom składającym się na kwestię opiekuńczą poświęciły uwagę. Pozytywnie należy w tym kontekście ocenić bardzo liczne i szczegółowe kontrole w tym obszarze Najwyższej Izby Kontroli, które zaowocowały nie tylko diagnozą różnych segmentów opieki (zarówno instytucjonalnej, jak i dziennej, skierowanej do osób z chorobą Alzheimera itp.), ale i całościowej polityki w tym zakresie na poziomie lokalnym, a także konkretnymi rekomendacjami, które mogłyby być wykorzystane w reformowaniu polityki senioralnej na poziomie systemowym. Także na uwagę zasługuje wielowymiarowe zaangażowanie Rzecznika Praw Obywatelskich w prawa osób zależnych od opieki i ich bliskich. Można wskazać działania w ramach Krajowego Mechanizmu Prewencji, przekrojowe raporty diagnozujące sytuację osób starszych i system ich wsparcia (zawierające również rekomendacje dla innych podmiotów polityki publicznych), a także działalność rzeczniczą na rzecz praw opiekunów niepełnosprawnych osób dorosłych (w tym starszych). Uwagę autora zwrócił także raport UOKiK, który ujawnił nieprawidłowości w prywatnym segmencie opieki oraz przyczynił się do wyeliminowania części z nich. Całokształt zaangażowania wskazanych podmiotów tworzy szeroki zakres dość pogłębionej wiedzy oraz wskazówek, w jaki sposób można z niej korzystać w poprawianiu systemu opieki długoterminowej nad osobami starszymi w Polsce.

\section{Bibliografia}

„Chcemy całego życia” - petycja dotyczaca godzenia pracy z pobieraniem świadczeń opiekuńczych, https://chcemycalegozycia.pl/nasza-petycja-ruszyla/

„Dom to praca” - kampania dotycząca godzenia pracy z pobieraniem świadczeń opiekuńczych, https://domtopraca.pl/zmien-prawo-pozwol-opiekunom-dorabiac/

Bakalarczyk R., Polityka wsparcia rodzin z osobami niepełnosprawnymi. W cieniu wyroków Trybunału Konstytucyjnego RP i protestów społecznych, „Studia z Polityki Publicznej” 2015, $\mathrm{nr} 1(5)$.

Bezpieczny i aktywny senior, http://senior.gov.pl/bezpieczny_i_aktywny_senior/strona/76

Birkland T., Agenda Setting in Public Policy, w: Handbook of Public Policy Analysis. Theory, Politics and Methods, red. F. Fischer, G.J. Miller, M.S. Sydney, CRS Press 2007, za: A. Zybała, Polityki publiczne. Doświadczenia w tworzeniu i wykonaniu programów publicznych $w$ Polsce $i$ w innych krajach, KSAP, Warszawa 2012. 
Błędowski P., Zaspokojenie potrzeb opiekuńczych osób starszych, w: Strategie działania w starzejacym się społeczeństwie. Tezy i rekomendacje. Raport RPO, red. B. Szatur-Jaworska, Warszawa 2012.

Eurofound, Working and Caring: Reconciliation Measures in Times of Demographic Change, październik 2015.

Furmańska-Maruszczak A., Systemy wspierania aktywności zawodowej rodziny opiekunów osób starszych, „Polityka Społeczna” 2015, nr 7.

Kraft M.E., Furlong S.R., Public Policy, Politics, Analysys, and Alternatives, CQPress, 2017.

Kraus M., Czypionka T., Riede M., Mot I.E.,Willeme P., How European Nations Care for Their Elderly? A New Typology of Long-Term Care Systems, 2011.

Łuczak P., Opiekunowie dorostych osób niepetnosprawnych $w$ Polsce i ich aktywność zawodowa, „Polityka Społeczna” 2017, nr 8.

Marska-Dzioba N., Świadczenia dla opiekunów w krajach Unii Europejskiej, „Ubezpieczenia Społeczne. Teoria i praktyka ZUS" 2015, nr 2(125).

MRPiPS, Sprawozdanie z realizacji Rzadowego Programu na rzecz Aktywności Społecznej Osób Starszych na lata 2014-2020 - rok 2015, Warszawa 2016.

Najwyższa Izba Kontroli, Informacja o wynikach kontroli „Opieka nad osobami chorymi na chorobę Alzheimera oraz wsparcie dla ich rodzin", Warszawa, kwiecień 2017.

Najwyższa Izba Kontroli, Informacja o wynikach kontroli „Opieka nad osobami starszymi w dziennych domach pomocy", maj 2017.

Najwyższa Izba Kontroli, Informacja o wynikach kontroli „Świadczenie pomocy osobom starszym przez gminy i powiaty", Warszawa, luty 2016.

Najwyższa Izba Kontroli, Informacja o wynikach kontroli funkcjonowania zakładów opiekuńczo-leczniczych, marzec 2010.

Najwyższa Izba Kontroli, Informacja o wynikach kontroli kierowania osób do domów pomocy społecznej i finansowania ich pobytu przez organy samorzadu terytorialnego, marzec 2010.

Opieka dhugoterminowa w Polsce. Opis. Diagnoza, rekomendacje, red. M. Augustyn, Warszawa 2009.

Perek-Białas J., Tradycyjne i uzupetniające podejścia do ewaluacji efektów polityki senioralnej, „Problemy Polityki Społecznej. Studia i Dyskusje” 2016, nr 34(3).

Ranci C., Pavolini E., Institutional Change in Long-term Care: Actors, Mechanisms and Impacts, $\mathrm{w}$ : Reforms in Long-term Care Policies in Europe Investigating Institutional Change and Social Impacts, red. C. Ranci, W. Pavolini, Springer, New York 2013.

Rzecznik Praw Obywatelskich, Prawa mieszkańców domów pomocy społecznej. Jak wspólnie zadbać o godne życie osób starszych, chorych i z niepetnosprawnościami? Raport z dziatalności RPO krajowego mechanizmu prewencji tortur, Warszawa 2017.

Rzecznik Praw Obywatelskich, Wniosek Rzecznika Praw Obywatelskich do Trybunału Konstytucyjnego, Warszawa, 24 czerwca 2013.

Stan przestrzegania praw osób starszych. Analiza i rekomendacje działań, Raport RPO, red. B. Szatur-Jaworska, Warszawa 2008. 
Stypińska J., Perek-Białas J., Working Carers in Poland - Successful Strategies of Reconciliation of Work and Care of an Adult, "Antropological Notebooks" 2014, Vol. 20.

Sytuacja osób chorych na chorobę Alzheimera, red. A. Szczudlik, Warszawa, maj 2014.

Sytuacja wsparcia osób starszych w środowisku zamieszkania. Przegląd sytuacji, propozycja modelu, red. P. Błędowski, B. Szatur-Jaworska, Raport RPO, Warszawa 2016.

Szatur-Jaworska B., Polityka senioralna w Polsce - analiza agendy, „Problemy Polityki Społecznej. Studia i Dyskusje" 2015, nr 30.

Szatur-Jaworska B., Polska polityka społeczna wobec starzenia się ludności w latach 1971-2013, Dom Wydawniczy Elipsa, Warszawa 2016.

Szlązak M., Piłat A., Sarata J., Opiekunowie rodzinni osób starszych - problemy, potrzeby, wyzwania dla polityki społecznej. Raport z badania, Regionalny Ośrodek Polityki Społecznej, Kraków 2015.

Topolewska M., Mało chętnych na dotację z programu „Opieka 75+”, „Dziennik Gazeta Prawna”, 1 lutego 2018.

Trafiałek E., Inowacyjna polityka senioralna, między ageizmem, bezpieczeństwem socjalnym $i$ active ageing, Wydawnictwo Adam Marszałek, Torun 2016.

Uchwała nr 157 Rady Ministrów z dnia 20 grudnia 2016 r. zmieniająca uchwałę w sprawie ustanowienia programu wieloletniego „Senior-WIGOR” na lata 2015-2020.

Uchwała nr 237 Rady Ministrów z dnia 24 grudnia 2013 r. w sprawie ustanowienia Rządowego Programu na rzecz Aktywności Społecznej Osób Starszych na lata 2014-2020.

Uchwała nr 238 Rady Ministrów z dnia 24 grudnia 2013 r. w sprawie przyjęcia dokumentu Założenia Długofalowej Polityki Senioralnej w Polsce na lata 2014-2020.

Uchwała nr 34 Rady Ministrów z dnia 17 marca 2015 r. w sprawie ustanowienia programu wieloletniego „Senior-WIGOR” na lata 2015-2020.

UOKiK, Domy opieki. Badanie wzorców umownych stosowanych w placówkach świadczacych ustugi w zakresie zapewnienia opieki osobom niepetnosprawnym, przewlekle chorym lub osobom w podeszlym wieku, Warszawa 2014.

Woźnicki J., Nowa dyscyplina - „nauki o polityce publicznej” usytuowana $w$ dziedzinie nauk społecznych, „Nauka” 2012, nr 1.

Wyrok Trybunału Konstytucyjnego z dnia 5 grudnia 2013 r., sygn. akt K 27/13. Uzasadnienie, http://ipo.trybunal.gov.pl/ipo/

Zybała A., Polityki publiczne. Doświadczenia w tworzeniu i wykonaniu programów publicznych $w$ Polsce i w innych krajach, KSAP, Warszawa 2012. 